\title{
A Record of Rotaloid Foraminifera from the Upper Permian-Lower Triassic Rocks of Kashmir, India
}

\author{
Prabhas Kumar Pande ${ }^{1 *}$ and S.P. Sharma ${ }^{2}$ \\ ${ }^{1}$ Ram Lal Anand College, University of Delhi, New Delhi-110021, India \\ (*prabhaspandey.geo@rla.du.ac.in). \\ ${ }^{2}$ Reliance Industries Ltd., RCP 10A $2^{\text {nd }}$ Floor, Thane Belapur Road, Navi Mumbai-400701, \\ India.
}

\begin{abstract}
The first record of Rotaloid foraminifera from the Upper Permian-Lower Triassic of Kashmir is significant as it provides an insight to understand organic evolution. The present study explicitly reveals that Rotaloid foraminifers' first origination was in Upper Permian in Peri-Gondwana Tethys and later migrated to other provinces of the world.
\end{abstract}

Keywords: Rotaloid Foraminifera, Upper Permian, Lower Triassic, Kashmir, India.

\section{INTRODUCTION}

In the history of organic evolution, the end of Palaeozoic Era was marked by the conspicuous event of mass extinctions. Amongst foraminifera, as many as fourteen families became extinct (Loeblich and Tappan, 1964) during the Permian Period and many new families evolved in the Mesozoic. There is a gap in the record of foraminifera from latest Permian and earliest Triassic because of the absence of marine strata representing this time span due to global regression of epicontinental seas. The Permian-Triassic transition represents a critical period in foraminiferal evolutionary history as the end-Permian mass extinction with few survivals and recovery intervals resulted in a dramatic turnover in the taxonomic composition of calcareous benthic assemblages (Grooves and Altiner, 2005; Ma'rquez, 2005).

Late Palaeozoic and early Mesozoic sequences are reasonably well known for the record of calcareous foraminifers. This is limited to occurrences in the Upper Permian Wuchiapingian and Changhsingian stages through the Lower Triassic Induan and Olenekian stages and demonstrates changes in generic diversity within the orders Fusulinida, Miliolida, Lagenida and Involutinida (Grooves and Altiner, 2005).

In Kashmir, uppermost Permian [Araksian (Dzhulfian)] and lowermost Triassic [Brahmanian (Induan)] shallow marine sediments are continuously well exposed at two localities in Vihi District, Srinagar, namely, Guryul ravine and a spur three kilometers north of Barus. The study 
of the Upper Permian foraminiferal assemblage from these sediments has shown the presence of rotaloid genera belonging to three families namely, Lenticulina Lamarck, Marginulina D’Orbigny, Vaginulinopsis Silvestri, Citharina D’Orbigny (Nodosariidae), Pyrulinoides Marie (Polymorphinidae) and Diplotremina Kristan-Tollman, Duostomina Kristan-Tollman (Discorbidae) in association with typical Permian forms. The presence of these genera in Zewan Formation extends their lower age limit to Upper Permian and suggests that Tethys remained the centre of origin and development for foraminifera well up to the close of the Permian.

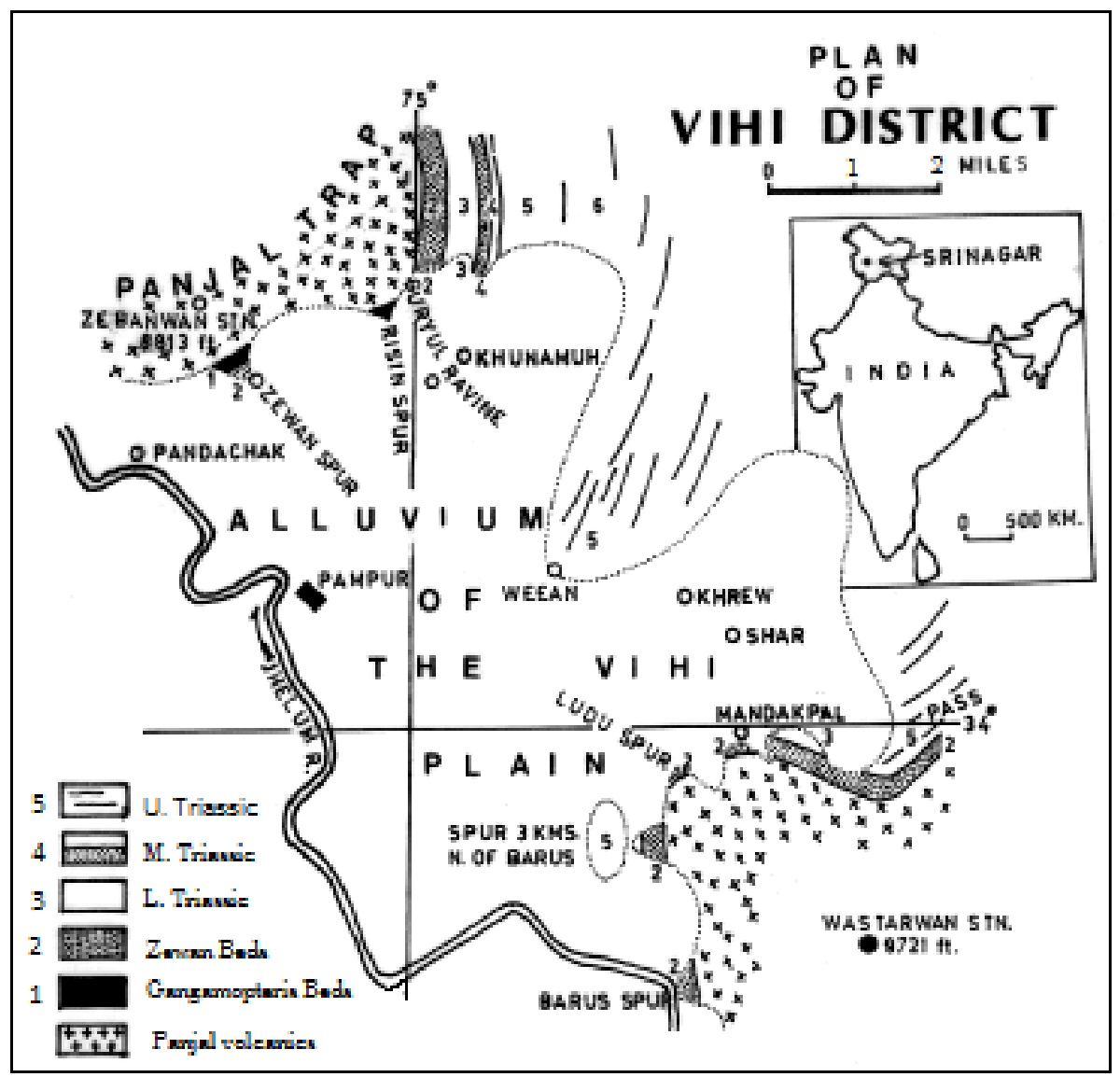

Figure 1. Map showing distribution of marine Permian-Triassic strata around Srinagar, Vihi District (After Middlemiss, record Geological Survey of India, 37 (4) Pl. 10, 1910). Dotted line indicates approximate boundary between hills and recent valley deposits.

\subsection{Geological Setting and Stratigraphic Background}

The Upper Permian marine sediments, represented by the Zewan Formation, are well exposed in many localities in Kashmir, India (Fig 1) with their best development at Guryul ravine, 16 kilometers south-east of Srinagar and at a spur, 3 kilometers north of Barus. The Guryul ravine section is represented by 97.3 meters thick succession of impure sandy limestone, calcareous 
sandstone, sandy and calcareous shale (Fig 2) (Nakazawa et al., 1975). At three kilometers north of Barus the Upper Permian strata attain a thickness of 125 meters (Nakazawa et al., 1975). The succession becomes increasingly calcareous in up-section and the succeeding Lower Triassic Khunamuh Formation consists of alternations of grey to black limestone intercalated with black shale layers. In the present paper we adopt the lithostratigraphic framework proposed by Nakazawa et al. (1975) subdividing the Zewan Formation into four (A-D) and the Khunamuh Formation into six (E-J) lithounits. Figure 2 summarizes the litho- and biostratigraphy of the Zewan Formation and lowermost part of the Khunamuh Formation.

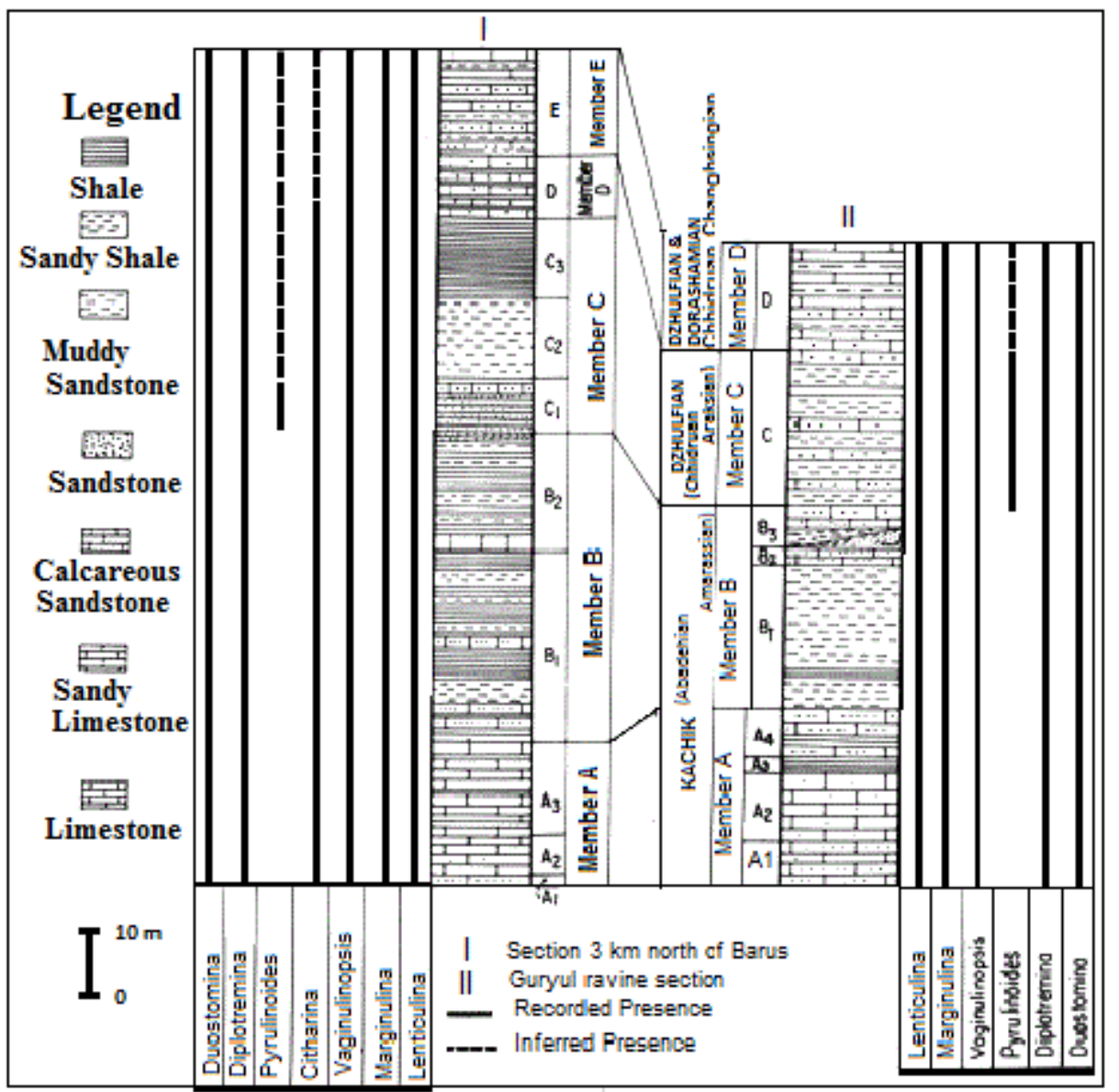

Figure 2. Distribution of Rotaloid foraminiferal genera in Zewan Formation (Guryul ravine section and section three kilometers north of Barus). Correlated lithologs after Nakazawa (Nakazawa et al., 1975, Nakazawa et al., 1981).

\section{MATERIAL AND METHODS}

The study is based on the presence of foraminiferal assemblage reported by the authors in their present and earlier work (Kalia and Sharma, 1985, Pande, 1989; Pande and Kalia, 1994) from the 
Upper Permian and the Lower Triassic horizons of these two successions of Kashmir. The successions are stratigraphically well constrained by earlier palaeontological and sedimentological studies (Nakazawa et al., 1975; Sweet, 1970; Teichert et al., 1970; Furnish et al., 1973; Kalia and Pande,1989; Pande and Kalia, 1994; Korte et al., 2010). Specimens described here are deposited in Department of Geology, Ram Lal Anand College (University of Delhi). Specimens are numbered with code KSF and GR which stands for Kashmir Smaller Foraminifera and Guryul Ravine respectively.

The foraminiferal assemblage obtained from closely sampled levels of the Zewan Formation in these two sections are characterized by the presence of typical Permian calc-microgranular forms, arenaceous forms and calcareous, perforate genera earlier recorded from Triassic or Jurassic onwards.

The present record of post-Palaeozoic genera from Zewan Formation namely Lenticulina Lamarck 1804, Marginulina D’Orbigny 1826, Vaginulinopsis Silvestri 1904, Citharina D’Orbigny 1839, Pyrulinoides Marie 1941, Diplotremina Kristan-Tollman 1960, Duostomina Kristan-Tollman 1960, in association with typical Permian foraminifera like Globivalvulina cyprica Reichel 1946, Lunucammina postcarbonica (Spandel) 1901, Lunucammina ovate (Lange) 1925, Nodosinella digitata Brady 1876, Tetrataxis conica Ehrenberg 1854, Glomospira simplex Harlton 1928, Ammobaculites texturata Cushman and Waters 1928, and Hemigordius calcarea Cushman and Waters 1928, brings down their lower age limit to the Upper Permian (Okimura and Ishii, 1981; Kalia and Sharma, 1985). Other characteristic Permian fauna reported by previous workers from the Zewan Formation (Nakazawa et al., 1975; Nakazawa and Kapoor, 1981) includes Marginifera himalayensis Diener, Waagenoconcha abichi (Waagen), Linoproductus lineatus (Waagen) [Brachiopods], Palaeolima sp., Eheripecten haydeni Nakazawa [Pelecypods], Dyscritella tenuirama Crockford, Acanthocladia anceps (Schlotheim), Stenodiscus chaetetiformis (Waagen and Wentzel) [Bryozoa], Anchignathodus typicalis Sweet [Conodont].

\section{RESULTS AND DISCUSSION}

\subsection{Foraminiferal Record}

Late Palaeozoic calcareous foraminiferal assemblages were dominated by the Order Fusulinida, including a variety of large and internally complex forms. Early Mesozoic assemblages, in 
contrast, are characterized mostly by morphologically simple miliolids and lagenids. Planktonic forms originated in Jurassic time, and Rotaloid, the dominant group of extant calcareous benthonic foraminifers, underwent their initial major expansion in Late Cretaceous time. The calcareous, perforate, radiate walled forms became prolific in Mesozoic in contrast to Palaeozoic foraminiferal assemblages characterized by calc-microgranular forms. The record of calcareous perforate forms from Permian was restricted to a few genera like, Nodosaria Lamarck 1812, Astacolus De Montfort 1808, and Frondicularia Defrance in D'Orbigny 1826, belonging to the family Nodosariidae.

The earlier record of genus Lenticulina Lamarck was from Triassic onwards only. There have been but only two reports of the occurrence of lenticulines from Permian. Lenticulina (Astacolus) oblonga Maklay 1960 (Maklay, 1964) was described from the Upper Permian of Russia and Lenticulina (Astacolus) initialis Crespin 1958 (Crespin, 1958) from NW Australia. Taxonomic position of Lenticulina (Astacolus) oblonga is questionable as it lacks a radiate aperture. The wall structure of Lenticulina (Astacolus) initialis Crespin was not commented upon sufficiently. It was thought that Permian lenticulines perhaps possessed a different wall structure and do not represent Lenticulina s str. (Brotzen, 1963). The species of Lenticulina occur vertically throughout the Zewan Formation and are characterized by a slightly trochospiral coil with a tendency to uncoil or having uncoiled later portion, radiate aperture and calcareous, radial, finely perforate wall (Figs 3.8 to 3.13 and Figs 4.2 to 4.7, 4.9, 4.11).

Although the specimens recovered from the Upper Permian of Kashmir are recrystallized to various degree, the wall structure has not been completely obliterated. The radial wall structure is quite clear in the thin sections of Lenticulina spp. shown in figures 3.18, and 3.19, although, in some of the segments recrystallization has caused slight thickening of fibers. Pande and Kalia (1994) described several genera of the family Vaginulinidae (Lenticulina, Marginulinopsis, Saracenaria, Astacolus, Marginulina and Vaginulinopsis) in thin-sections as well.

Besides Lenticulina Lamarck other post-Palaeozoic nodosariid genera recorded from the Upper Permian of Kashmir include, Marginulina D’Orbigny, Vaginulinopsis Silvestri and Citharina D'Orbigny. The genera Vaginulinopsis and Citharina were known earlier only from Jurassic onwards. Vaginulinopsis spp. is recorded throughout the Zewan Formation (Fig 2) and Citharina is recorded from unit A3 and Member D at three kilometers north of Barus (Fig 2). 


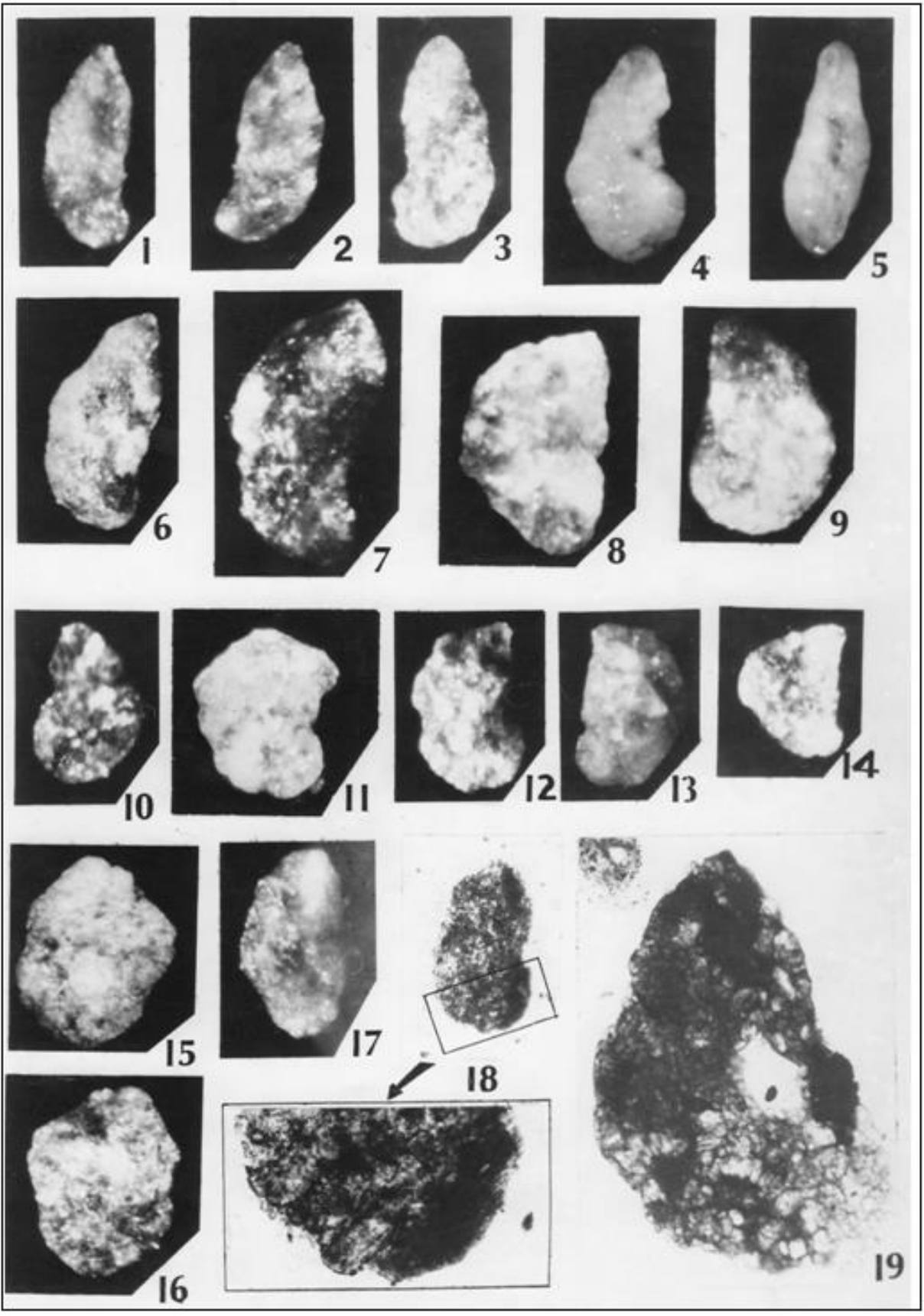

Figure 3. Vaginulinopsis sp. A (1\&2 showing opposite sides, x110); Vaginulinopsis sp. A (3x60); Vaginulinopsis sp. B (4 \& 5 showing side and edge views, x65); Marginulina spp. (6x80, 7x70); Lenticulina spp. (8,13 x85; 9x100; 10x60; 11x45; 12x65); Citharina sp. (14x85); Diplotremina sp. (15-17 x85); Lenticulina sp. (Horizontal section (18x95) and coiled portion blown up (x172) showing the radial calcareous wall; Lenticulina sp. (Horizontal section (19x150) showing thickened fibers of radiate wall in the last two chambers on the outer margin and conversion of fibers into sparry mosaic on the inner margin. The coiled portion is intensely recrystallized and development of sparry calcite has completely obliterated the wall structure. 


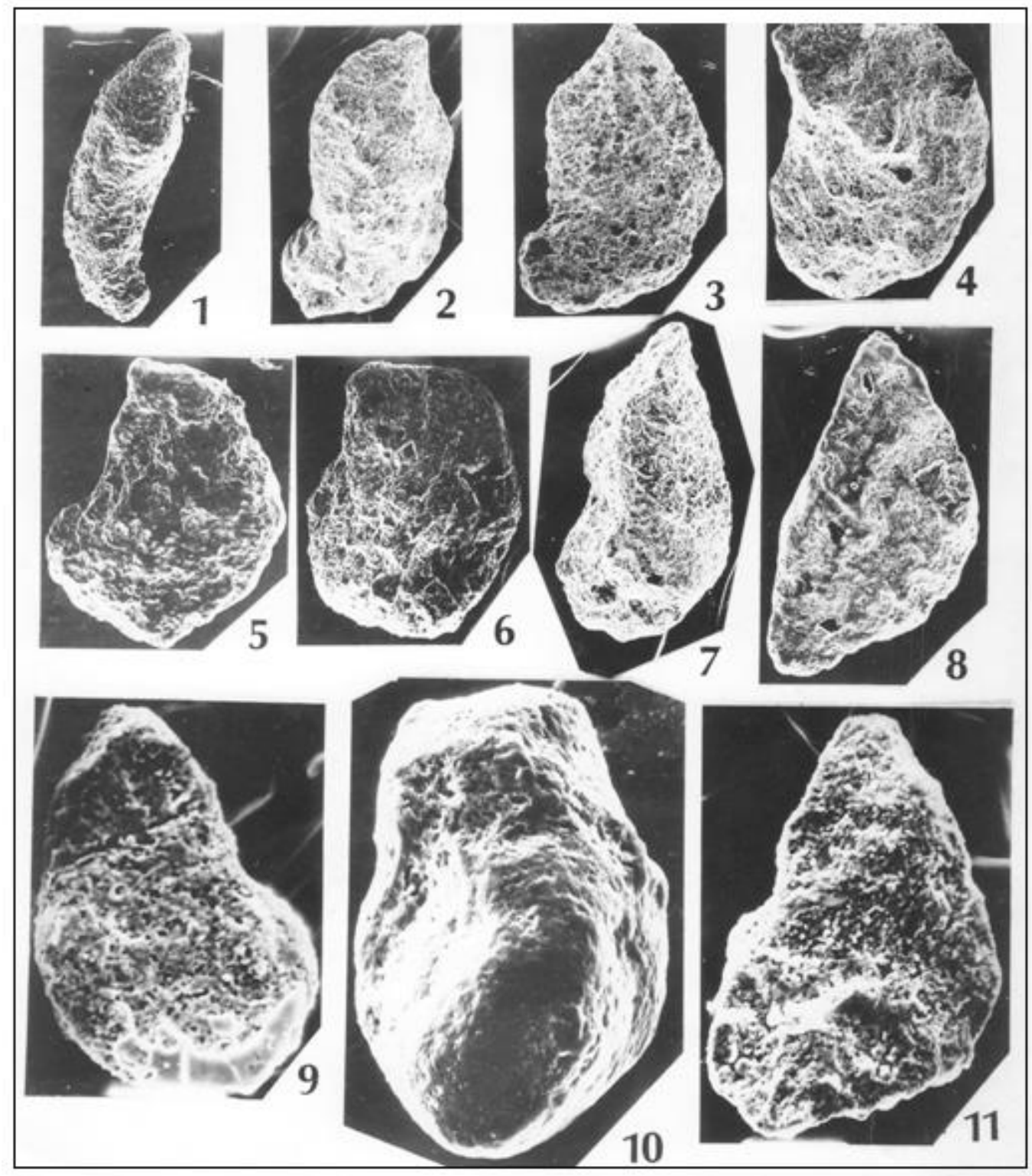

Figure 4. Scanning Electron Microphotographs showing Marginulina sp. (1x90); Lenticulina spp. [(2-4 (x110), 5-6 (x140), 7 (x100), 9(x160), 11(x180)]; Citharina sp. (8x100); Duostomina sp. (10x180).

The specimens obtained are slightly recrystallized and sutures are visible only after dampening the specimens. Vaginulinopsis spp. are characterized by an early coiled stage and later uncoiling along a straight axis (Figs 3.1 to 3.5). Citharina sp. is characterized by a flattened sub-triangular, smooth test with chambers extending nearly to the base at inner margin and radiate aperture (Figs 3.14 and 4.8). Specimens belonging to Marginulina spp. in the present study (Figs 3.6, 3.7 and 4.1) and that described earlier (Kalia and Sharma, 1985; Pande and Kalia, 1994) represent 
two to three different species. The polymorphines which were considered to have arisen in postPalaeozoic times only are represented by a single genus Pyrulinoides Marie in the Upper Permian strata of Kashmir. The genus Pyrulinoides Marie has a known lower age limit of Upper Triassic. In the Zewan Formation Pyrulinoides sp. appears in Member $\mathrm{C}$ at both the localities studied (Fig 2). It is characterized by biserially arranged, embracing chambers in a fusiform test with flush, oblique sutures and radiate aperture.

The discorbid genera Duostomina Kristan-Tollman and Diplotremina Kristan-Tollman were described from Middle Triassic of Austria (Kristan-Tollman, 1960). Few forms belonging to these genera recorded from Zewan Formation are characterized by a low trochospiral coil and fimbriate aperture at the anterior margin of the test (Figs 3.15 to 3.17; Fig 4.10). The wall structure is not very clear but can be inferred to be radial, perforate as the thin sections of individual specimens of these forms show development of sparry mosaic in the wall portion of the test (Cummings, 1956).

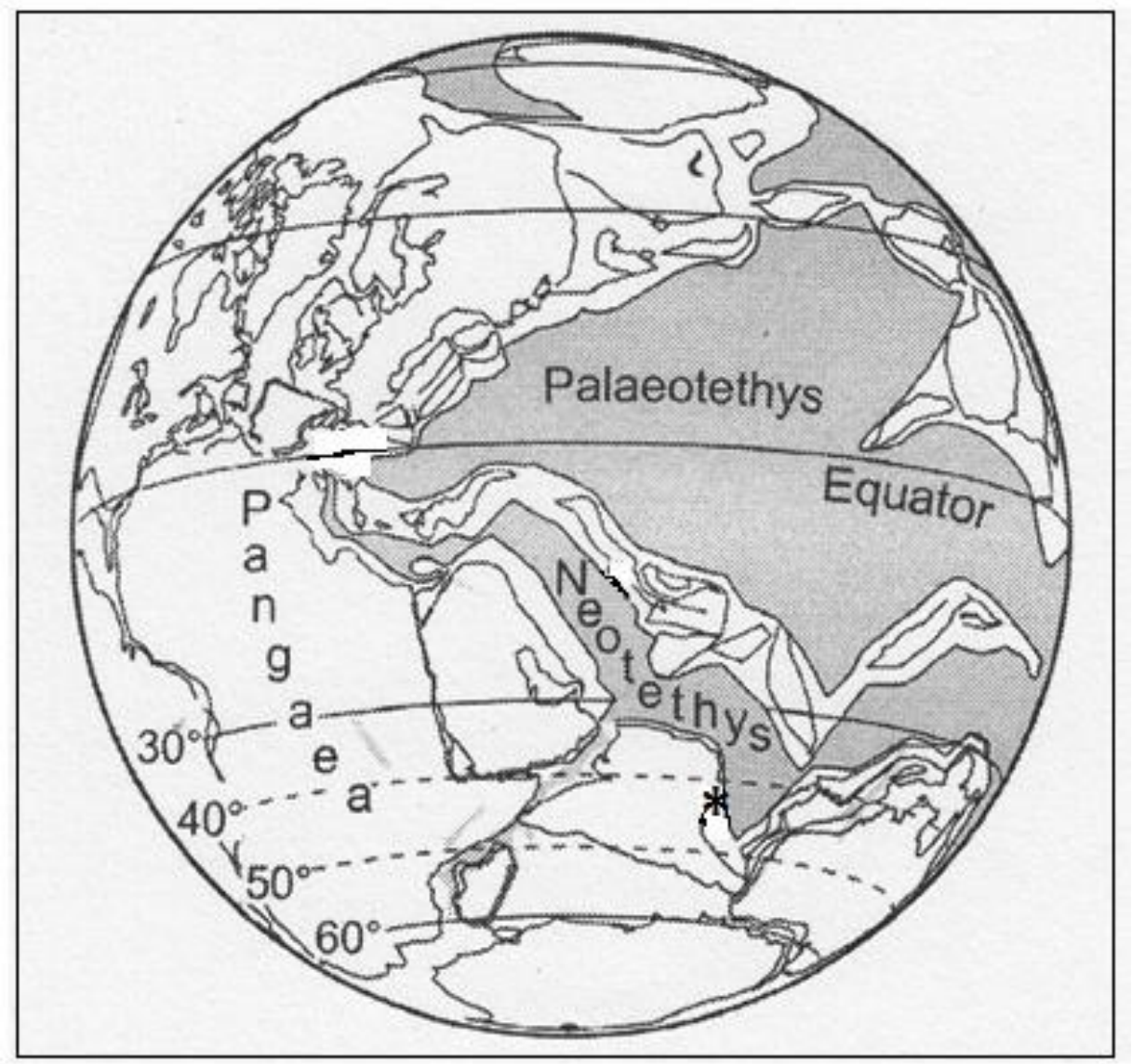

Figure 5. Palaeogeographic map of the Late Permian at 260 Ma (Modified after Korte et al., 2010 (Note: *Indicate location of Guryul Ravine section, Kashmir). 
The Guryul ravine section (Fig 5) was also studied for carbon and oxygen isotopes and their comparison with Abadeh, Iran and Southern Alps, Italy were carried out to understand the breakdown in biological productivity through these important Permian -Triassic transition levels representing mass extinctions (Korte et al., 2010).

\section{CONCLUSION}

The centre of development for Rotaloid foraminifera are considered to be the Tethys well up to the end of Carboniferous (Mamet, 1977). The occurrence of the early representatives of the families Nodosariidae, Discorbidae and Polymorphinidae in the Upper Permian (Kachik to Dorashamian) of Kashmir, India, suggests that the Tethys remained the centre of origin for foraminifera well up to the close of Palaeozoic Era and in the earliest Triassic as well. The Rotaloid fauna from the Upper Permian of Kashmir India is comparable to the assemblage reported from the Middle and Upper Triassic of Austria by Kristan-Tollman (Kristan-Tollman, 1960 \& 1964) Vaginulinopsis sp. A has a striking resemblance to Upper Triassic Lenticulina (Vaginulinopsis) ardua Kristan-Tollman 1964, reported from Austria. Likewise, Vaginulinopsis sp. B recorded from the Upper Permian of Kashmir closely resembles Lenticulina (Vaginulinopsis) insecta Kristan-Tollman 1964. Besides, Duostomina alta Kristan-Tollman 1960, Duostomina sp. and Diplotremina sp. Kristan-Tollman 1960, described from the Middle Triassic of Austria are also now recorded from the Upper Permian (Kachik to Dorashamian) of Kashmir.

The occurrence of above mentioned Rotaloid foraminifera in the Upper Permian of Kashmir suggests that Rotaloid foraminifera with calcareous radial, finely perforate wall and radiate aperture appeared and developed in various morphological types in latest Permian in the PeriGondwana Tethys and later migrated to other provinces of the world during Mesozoic palaeogeographic rearrangements. This also corroborates well with the interpretation of Korte et al. (2010) that Kashmir during the latest Permian and earliest Triassic belonged to the midlatitude cool-water Peri-Gondwana faunal province, rather than to the warm-water Tethyan Province. The latter conclusion was based on the conodont association of H. typicalis and C. carinata in the upper third of Member D and the common presence of ammonoid Otoceras woodwardi (Griesbach) in Member E2 of Guryul Ravine section, Kashmir. 
Abundant and diverse foraminifers from Permian-Triassic boundary strata at Meishan section (Song et al., 2007) and Late Permian Wujiaping Formation at Laren, Guangxi Province, South China (Gaillot et al., 2009) shows total absence of Rotaloid foraminifer genera. Even detailed discussion on Palaeozoic foraminifera from various parts of the world has no mention of these Rotaloid genera (Varchard et al., 2010). The Rotaloid assemblage recorded from Zewan Formation has a close affinity with the foraminiferal assemblages described from Middle and Upper Triassic of Austria. The Rotaloid genera and species first appeared in Upper Permian in Peri-Gondwana Tethys and later migrated to other parts of the world.

\section{ACKNOWLEDGEMENTS}

Authors are thankful to Prof. Prabha Kalia for her immense cooperation and guidance.

\section{REFERENCE}

Brotzen, F. 1963. Evolutionary trends in certain Calcareous foraminifera on the PalaeozoicMesozoic boundary. In: Von Koenigswald, G.H.R. (ed.), Evolutionary trends in foraminifera. Elsevier, Amsterdam, London, New York, 66-78.

Crespin, I. 1958. Permian Foraminifera of Australia. Commonwealth Australia, Bureau of Mineral Resources, Geology and Geophysics Bulletin, 48:1-207.

Cummings, R. H. 1956. Revision of the Upper Palaeozoic textulariid Foraminifera. Micropaleontology, 2(3):201-242.

Furnish, W.M., Glenister, B.F., Nakazawa, K \& Kapoor, H.M. 1973. Permian ammonoid Cyclolobus from Zewan Formation, Guryul ravine, Kashmir. Science, 180:188-190.

Gaillot J., Varchard D., Galfetti T \& Martini M. 2009. New latest Permian foraminifers from Laren (Guangxi Province, South China): Palaeobiogeographic implications. Geobios, 42:141-168.

Groves J.R \& Altiner, D. 2005. Survival and recovery of calcareous foraminifera pursuant to the end-Permian mass extinction. Competes Rendus Palevol, 4:487-500.

Kalia, P \& Sharma, S.P. 1985. Upper Permian Foraminifera from the Zewan Formation, Kashmir, India. In: Samanta, B.K. (ed.): Proceedings XI Indian Colloquium on Micropaleontology and Stratigraphy. Bulletin Geological Mining \& Metallurgical Society of India, 52:37-69. 
Korte, C., Pande, P., Kalia P., Kozur H. W., Joachimski M. M \& Oberhansli H. 2010. Massive volcanism at the Permian-Triassic boundary, and its impact on the isotopic composition of the ocean and atmosphere. Journal of Asian Earth Science, 37:293-311.

Kristan-Tollman, E. 1960. Rotaliidea (Foraminifera) aus der Trias der Ostalpen. Geol. Bundensanstalt, Jahrb. Special volume, 5:47-48.

Kristan-Tollman, E. 1964. Die foraminiferen aus den rhatischen. Zlaunbachmergein der fischerwiese bei Aussee in Salzkammergut Austria. Geol. Bundesanst., Jahrb. Vienna, Sonderband, 10:1-189.

Loeblich, A.R \& Tappan, H. 1964. Sarcodina, chiefly "Thecamoebians" and Foraminiferida. In: Moore, R.C. (ed.), Treatise on Invertebrate palaeontology, C: Protista 2 (1\&2).

Maklay, M. 1964. Novye Rannekamennougolnye Arkhedistsidy in: Novye vidy drevnikh rudteniy i bespozvonochrrykh SSSR Pt 1. Vsesoyuznyy Nauchno Issledovatelskii Geologicheskii Institut (VSEGEI): Min. Geol. Okhrana. Nedr. USSR, 1:158-159.

Mamet, B. 1977. Foraminiferal zonation of the Lower Carboniferous in Kaufman, E.G. and Hazel, J.E. (eds.), Concepts and methods of biostratigraphy. Dowden, Huchinson and Ross, Inc, 445-462.

Ma'rquez, L. 2005. Foraminiferal fauna recovered after the Late Permian extinctions in Iberia and the westernmost Tethys area. Palaeogeography, Palaeoclimatology, Palaeoecology, 229:137- 157 .

Nakazawa, K., Kapoor, H.M., Ishii, K., Bando, Y., Okimura, Y \& Takuoka, T. 1975. The Upper Permian and Lower Triassic in Kashmir, India. Memoir Faculty of Science, Kyoto University, 42(1):1-106.

Nakazawa, K \& Kapoor, H.M. 1981. The Upper Permian and Lower Triassic Faunas of Kashmir. Memoir Geological Survey of India, Palaeontologia Indica, 46:1-204.

Okimura, Y \& Ishii, K. 1981. Upper Permian and Lower Triassic Foraminifera from Guryul ravine and spur three kilometers north of Barus. In: Nakazawa, K. \& Kapoor, H.M. (eds.), The Upper Permian and Lower Triassic Faunas of Kashmir. Memoir Geological Survey of India, Palaeontologia Indica, 46:25-38.

Pande, P.K. 1989. Duostominids from Permian-Triassic sequence of Himalaya. Proceedings of XII Indian Colloquium on Micropalaeontology and Stratigraphy, Papyrus Publications, 206-218. 
Pande, P. K \& Kalia, P. 1994. Upper Permian and Lower Triassic nodosariid foraminifera from the Kashmir Himalaya, India. Neues Jahrbuch für Geologie und Paläontologie Abhandlungen, 191:313-329.

Song H.J., Tong J.N., Zhang K.X., Wang Q.X \& Chen, Z.Q. 2007. Foraminiferal survivors from the Permian-Triassic mass extinction in the Meishan section, South China. Palaeoworld, 16:105-119

Sweet, W.C. 1970. Permian and Triassic conodonts from a section at Guryul ravine, Vihi district. University of Kansas, Pal Institute paper, 49:1-10.

Teichert, C., Kummel, B \& Kapoor, H.M. 1970. Mixed Permian-Triassic fauna, Guryul ravine, Kashmir. Science 167:174-175.

Vachard, D., Pille, L \& Gaillot, J. 2010. Palaeozoic Foraminifera: Systematics, palaeoecology and responses to global changes. Revue de Micropaléontologie, 53:209-254. 